\title{
COMPARATIVE STUDY OF THE EFFECT OF CAMPHOR HONEY BEE AND CAMPHOR OIL ON SOME BIOLOGICAL AND PRODUCTIVITY CHARACTERS OF MULBERRY SILKWORM, Bombyx mori L. \\ Saad M. S. I.; Eman M. Hassan and I. A. I. Saad \\ Sericulture Research Department (SRD), Plant Protection Research Institute (PPRI), Agricultural Research Center (ARC), Egypt.
}

\begin{abstract}
The effect of camphor honey and camphor oil (1, 2, 3, 4 and 5\%) on the growth and silk production of mulberry silkworm Bombyx mori L. was investigated. It was found that camphor honey bee (5\%) and camphor oil (1\%) increased the grown larval weight, silk gland weight, cocoon weight, cocoon shell weight, silk content ratio, and represented by $(3.78$ and $4.076 \mathrm{gm}) ;(0.872$ and $1.050 \mathrm{gm}) ;(1.730$ and $1.668 \mathrm{gm})$; $(0.284$ and $0.284 \mathrm{gm})$ and $(1.204$ and $1.216 \%)$, respectively. Moreover, camphor honey bee $5 \%$ and camphor oil $1 \%$ increased also silk filament length, silk filament weight and silk filament size and represented by (1051.40 and $1059.80 \mathrm{~m}) ;(0.28$ and $0.27 \mathrm{gm}$ ) and (3.39 and $3.39 \mathrm{dn}$.), respectively.
\end{abstract}

Keywords: Silkworm, Bombyx mori, camphor, antibiotic, biology, honey bee.

\section{INTRODUCTION}

Nutritional value of mulberry leaves plays an important role in the growth of larvae, as well as silk production Legay (1958). Some food additives to mulberry leaves were evaluated to improve the production and growth Sengupta et al. (1992). Also Zannoon (1994) reported that, various solutions of bee honeys increased the mean weight of the mature larvae, silk gland, fresh cocoons, cocoon cortex and the number of deposited eggs per female. Moreover, it gave heavier and longer filaments of reeled cocoons, but did not affect on cocoon silk content ratio and filament size. Eucalyptus oil (EO) has antibacterial, antiviral, and antifungal components and a long history of use against the effects of colds, influenza, other respiratory infections, rhinitis, and sinusitis, Angela and Davis, (2010). Using of camphor honey and camphor oil as nutritional additives for mulberry leaves to improve the production and a disinfectant against diseases that might infect the larvae at different ages because of its antiseptic effect against fungi and bacteria. There are many factors that influence the success of production of silk. In recent years, some antibiotic agents have been used for growth enhancement of silkworm larvae and improvement of production, Thilagavathi et al. (2013). Silkworm is affected by several diseases and at time causes heavy crop losses. Various chemicals (antibiotics) are extensively employed to prevent the attack of diseases to the silkworm thereby, help in, increasing the productivity of silk. Radha et al. (1980) and Anonymous (1980). The present study aimed to evaluate the effect of the camphor honey bee and camphor oil as nutritional additives on silkworm $B$. mori to improve its growth and productivity. 


\section{MATERIALS AND METHODS}

The present experiments were carried out during spring season of 2013 in laboratories of Sericulture Research Department, Plant Protection Research of Sharkia Branch, Institute, Agriculture Research Center, Egypt to study the biological and technological effects of camphor honey bee and camphor oil as a nutritional additive on silkworm Bombyx mori larvae growth.

\section{Materials:}

1-The hybrid mulberry silkworm Bombyx mori (local hybrid).

2-Camphor honey bee prepared by dissolving $50 \mathrm{ml}$ of camphor honey in $1000 \mathrm{ml}((50 \mathrm{ml}$ honey/1000) $\times 100)$ of distilled water to prepare a concentration of $5 \% ; 40 \mathrm{ml}$ of honey to prepare a concentration of $4 \%$; and so the remaining concentrations. Used concentration cleared at the following.

3- Camphor oil from Eucalyptus sp. leaves. Prepared by Harvey and John (1898).

\section{Silkworm rearing technique:}

Rearing of silkworm was carried out under laboratory conditions (28 \pm $2^{\circ} \mathrm{C}$ and $70 \pm 5 \%$ R.H.) without any adjustment or changes in temperature or relative humidity according to the technique of Krishnaswami (1978). The larval bed was cleaned daily. Cleaning net was used for removing the remained dried food and feces. Chicken egg cartons plates were used as montages for cocoon spinning Zannoon and Omera (1994).

\section{Methods:}

Larvae under investigation were divided into two groups. Every group was divided to five subgroups to fed on mulberry leaves supplemented with camphor honey or camphor oil concentrations one meal at the first day of the $4^{\text {th }}$ instar after molting and another time in the mid of the same instar. Three replicates (100 larvae) for each. Mulberry leaves were dipped in the concentrations of treated camphor oil and honey for 5 minute and left to dry then offered to larvae. The control group of leaves was treated only with distilled water.

The following parameters were studied:

Biological aspects: Larval weight (gm); Silk gland weight (gm).

Cocoon indices: weight of fresh cocoon (gm); Weight of cocoon shell (gm); Silk content ratio (\%): Silk content ratio was calculated according to Tanaka (1964) formula:

$$
\text { Silk content ratio }(\%)=\frac{\text { weight of cocoon shell }(\mathrm{mg})}{\text { weight of fresh cocoon }(\mathrm{mg})} \times 100
$$

Filament characters: Length of reelable filament $(\mathrm{m})$; Weight of reelable filament (gm); Size of reelable filament (dn), Tanaka (1964): Size of silk filament $(\mathrm{dn})=.($ Weight of filament $(\mathrm{gm}) /$ Length of filament $(\mathrm{m}) \times 9000$.

\section{Statistical analysis}

Data obtained were statistically analyzed according to Snedecor and Cochran (1967) methods using computer software Costat program. 


\section{RESULTS AND DISCUSSION}

\section{Biological aspects:}

According to biological aspects, results of using camphor honey and camphor oil revealed significant increase in biological aspects than control as follows:

\section{Larval weight (gm.):}

Data in Table (1) revealed that larvae fed on mulberry leaves supplemented with camphor honey $(5 \%)$ and camphor oil(1\%) showed a significant increases about $(26.75 \%)$ and $(30.67 \%)$ in larval weights, respectively. While a significant decrease about $(3.70 \%)$ was caused when larvae fed on leaves treated with camphor honey (1\%). Results showed that there are high significant differences between the treatments, as well as concentrations

Table (1): Effect of camphor honey and camphor oil on some biological characters of silkworm, B. mori L.

\begin{tabular}{|c|c|c|c|c|c|}
\hline Treatment & Conc. & $\begin{array}{c}\text { Larval weight } \\
\text { (gm) }\end{array}$ & Changes (\%) & $\begin{array}{c}\text { Silk gland } \\
\text { weight (gm) }\end{array}$ & $\begin{array}{c}\text { Change } \\
(\%)\end{array}$ \\
\hline \multirow{5}{*}{ Camphor honey } & $1 \%$ & 2.872 & -3.70 & 0.704 & -8.81 \\
\hline & $2 \%$ & 3.468 & 16.29 & 0.712 & -7.77 \\
\hline & $3 \%$ & 3.466 & 16.22 & 0.776 & 0.52 \\
\hline & $4 \%$ & 3.570 & 19.71 & 0.808 & 4.66 \\
\hline & $5 \%$ & 3.780 & 26.75 & 0.872 & 12.95 \\
\hline Mean & & 3.431 & & 0.774 & \\
\hline \multirow{5}{*}{ Camphor oil } & $1 \%$ & 4.076 & 30.67 & 1.050 & 36.10 \\
\hline & $2 \%$ & 3.704 & 24.19 & 0.942 & 28.02 \\
\hline & $3 \%$ & 3.428 & 14.20 & 0.990 & 28.23 \\
\hline & $4 \%$ & 3.274 & 9.78 & 0.978 & 26.68 \\
\hline & $5 \%$ & 3.322 & 11.93 & 0.976 & 26.45 \\
\hline Mean & & 3.539 & & 0.952 & \\
\hline Control & & 2.982 & & 0.772 & \\
\hline LSD* & & $0.310^{\star *}$ & & $0.097^{* *}$ & \\
\hline LSD $^{\star \star}$ & & $0.377^{*}$ & & $0.063^{* *}$ & \\
\hline
\end{tabular}

${ }^{\star}$ L.S.D 0.05 for concentration ${ }^{\star \star}$ LSD 0.05 for treatment

\section{Silk gland weight (gm.):}

Obtained data in Table (1) cleared that larvae fed on mulberry treated with camphor honey (5\%) presented a significant increase of silk gland weight (12.95\%) compared with control, while the low concentrations of 1 and $2 \%$ showed a negative values. On the other hand, camphor oil at all concentrations (especially 1,2 and $3 \%$ recorded the highest significant values in comparison to control.

According to the obtained results, it could be concluded that feeding silkworm larvae on mulberry leaves treated with high concentrations of camphor honey and, lowest concentrations of camphor oil enhanced the Larval weight and silk gland weight of silkworm These results can be supported by Sengupta et al. (1992), Zannon (1994), El-Sayed et al. (1998), Khalil et al. (2006), Fathy et al. (2008), Zannon et al. (2008) and Gad (2013) 
who reported that improvement of mulberry leaves with some concentrations of honey bee leaded to increase the larval growth.

\section{Technological aspects:}

\section{Cocoon indices:}

Cocoon indices represented the most important indices in silk production.

\section{Cocoon weight (gm.):}

The highest mean weight of cocoons was increasingly about $55.28 \%$ at $5 \%$ concentration of camphor honey, and about $49.20 \%$ at $1 \%$ concentration of camphor oil, respectively in comparison to the control (Table 2). Results showed that there are high significant differences between the treatments, as well as concentrations.

\section{Cocoon shell weight:}

Data obtained in Table (2) showed that, the larvae fed on mulberry leaves treated with camphor honey $(5 \%)$ and camphor oil $(1 \%)$ caused increases in produced cocoon shells weight about 26.79 and $26.78 \%$, respectively higher than control. While, decreases observed at low concentrations (1 and $2 \%$ ) of camphor honey and highest concentration (5\%) of oil treatments.

Table (2): Effect of camphor honey and camphor oil on cocoon indices of silkworm, B. mori L.

\begin{tabular}{|c|c|c|c|c|c|c|c|}
\hline Treatment & Conc. & $\begin{array}{c}\text { Cocoon } \\
\text { weight }(\mathrm{gm})\end{array}$ & \begin{tabular}{|c|} 
Changes \\
$(\%)$
\end{tabular} & $\begin{array}{c}\text { Cocoon Shell } \\
\text { weight (gm) }\end{array}$ & $\begin{array}{c}\text { Changes } \\
(\%)\end{array}$ & \begin{tabular}{|c|}
$\begin{array}{c}\text { Silk ratio } \\
(\%)\end{array}$ \\
\end{tabular} & $\begin{array}{c}\text { Changes } \\
(\%)\end{array}$ \\
\hline \multirow{5}{*}{$\begin{array}{l}\text { Camphor } \\
\text { honey }\end{array}$} & $1 \%$ & 1.152 & 3.04 & 0.216 & -3.57 & 0.976 & 2.95 \\
\hline & $2 \%$ & 1.302 & 16.46 & 0.222 & -0.89 & 1.046 & 10.34 \\
\hline & $3 \%$ & 1.328 & 18.78 & 0.232 & 3.57 & 1.076 & 13.50 \\
\hline & $4 \%$ & 1.354 & 21.11 & 0.244 & 8.93 & 1.182 & 24.68 \\
\hline & $5 \%$ & 1.736 & 55.28 & 0.284 & 26.79 & 1.204 & 27.00 \\
\hline Mean & & 1.374 & & 0.240 & & 1.097 & \\
\hline \multirow{5}{*}{ Camphor oil } & $1 \%$ & 1.668 & 49.20 & 0.284 & 26.78 & 1.216 & 22.41 \\
\hline & $2 \%$ & 1.350 & 20.75 & 0.250 & 11.01 & 1.152 & 20.14 \\
\hline & $3 \%$ & 1.334 & 19.32 & 0.242 & 8.03 & 1.136 & 19.65 \\
\hline & $4 \%$ & 1.274 & 13.95 & 0.236 & 5.35 & 1.118 & 19.48 \\
\hline & $5 \%$ & 1.194 & 6.80 & 0.222 & -0.89 & 0.988 & 19.19 \\
\hline Mean & & 1.366 & & 0.246 & & 1.118 & \\
\hline Control & & 1.118 & & 0.224 & & 0.948 & \\
\hline LSD* & & $0.088^{\star *}$ & & $0.035^{\star *}$ & & $0.065^{\star *}$ & \\
\hline LSD $^{\star \star}$ & & $0.225^{*}$ & & ns & & $0.101^{* *}$ & \\
\hline
\end{tabular}

\section{Silk content Ratio:}

The results obtained in (Table 2) showed positive increases between the used concentrations of treatments and silk ratio ranged from $2.95 \%$ to $27.00 \%$ and from $22.41 \%$ to $19.19 \%$ when fed on leaves treated with camphor honey and camphor oil, respectively. Results showed that there are high significant differences between the treatments, as well as concentrations.

The present results agree with, Radha et al. (1980), Shoukry et al. (1998) and El-Sayed and Mosbah (1992) who stated that, volatile oils as nutritional additives improved the biological and technological characters of 
silkworm. Wang and Johnson (2001), Panfili et al. (2003) and Hassan and Saad (2012) investigated the efficiency of different concentrations of germ wheat oil was as a nutritional additive offered to silkworm larvae. Mulberry leaves supplemented with wheat oil were offered to larvae $4^{\text {th }}$ instar enhanced significantly all biotechnological characters. Also, Saad et al. (2012) and Thilagovathi et al. (2013) who reported that there are many factors that influence the success of production of silk. In recent years, some antibiotic agents have been used for growth enhancement of silkworm larvae and improvement of production. Moreover, Konala et al. (2013) reported that the using bovine milk to feed silkworm larvae has led to observes increase about $82 \%$ for larval weight compared to the control, as well as cocoon indices up to $8 \%$. In the same trend, Saad et al. (2014) found that the growth of the larvae, the weight of fresh cocoon, pupae and cocoon shell were significantly increased with glycine supplementation.

Filament Characters:

Filament length $(\mathbf{m}$.$) :$

Data tabulated in Table (3) cleared that the filament length was higher than control by $(25.60$ and $26.60 \%)$ when larvae fed on leaves treated with camphor honey and camphor oil at concentration of $5 \%$ and $1 \%$, respectively. Results showed that there are high significant differences between the treatments, as well as concentrations.

Table (3): Effect of camphor honey and camphor oil on silk filament characters of silkworm, B. mori L.

\begin{tabular}{|c|c|c|c|c|c|c|c|}
\hline Treatment & Conc. & $\begin{array}{c}\text { Silk } \\
\text { filament } \\
\text { Length }(\mathrm{m})\end{array}$ & $\begin{array}{c}\text { Changes } \\
(\%)\end{array}$ & $\begin{array}{c}\text { Silk } \\
\text { filament } \\
\text { Weight (gm) }\end{array}$ & $\begin{array}{c}\text { Changes } \\
(\%)\end{array}$ & \begin{tabular}{|c|} 
Silk \\
filament \\
Size (dn.)
\end{tabular} & $\begin{array}{c}\text { Changes } \\
(\%)\end{array}$ \\
\hline \multirow{5}{*}{ Camphor honey } & $1 \%$ & 894.60 & 6.87 & 0.21 & 4.57 & 2.27 & 0.00 \\
\hline & $2 \%$ & 920.00 & 9.90 & 0.21 & 4.57 & 2.29 & 1.32 \\
\hline & $3 \%$ & 920.60 & 9.98 & 0.21 & 7.61 & 2.31 & 2.03 \\
\hline & $4 \%$ & 977.40 & 16.76 & 0.24 & 19.79 & 2.96 & 30.80 \\
\hline & $5 \%$ & 1051.40 & 25.60 & 0.28 & 43.15 & 3.39 & 49.69 \\
\hline Mean & & 952.80 & & 0.23 & & 2.65 & \\
\hline \multirow{5}{*}{ Camphor oil } & $1 \%$ & 1059.80 & 26.60 & 0.27 & 39.08 & 3.39 & 49.69 \\
\hline & $2 \%$ & 972.60 & 16.18 & 0.25 & 25.88 & 2.59 & 14.47 \\
\hline & $3 \%$ & 958.60 & 14.51 & 0.23 & 17.76 & 2.47 & 9.00 \\
\hline & $4 \%$ & 946.00 & 13.00 & 0.20 & 3.55 & 2.40 & 6.00 \\
\hline & $5 \%$ & 941.00 & 12.41 & 0.19 & -3.55 & 2.35 & 3.62 \\
\hline Mean & & 971.80 & & 0.23 & & 2.64 & \\
\hline Control & & 837.10 & & 0.197 & & 2.27 & \\
\hline LSD* $^{*}$ & & $32.471^{\star \star}$ & & $0.013^{\star *}$ & & $0.204^{\star *}$ & \\
\hline LSD $^{\star *}$ & & $63.258^{* \star}$ & & $\mathrm{ns}$ & & ns & \\
\hline
\end{tabular}

* L.S.D 0.05 for concentration ${ }^{\star \star}$ LSD 0.05 for treatment

\section{Filament weight (gm):}

The obtained results indicated also that the weight of the silk filament increased (43.15 and 39.08\%) when larvae fed on mulberry leaves treated with camphor honey and camphor oil at concentration of $5 \%$ and $1 \%$, respectively. Statistical analysis revealed that there are high significant 
differences between the concentrations, while no significant differences between treatments.

Silk filament size (dn.):

Silk filament size presented an increase (49.69\%) comparing control when the larvae fed on mulberry leaves treated with camphor honey and camphor oil at concentration of $5 \%$ and $1 \%$, respectively. All used concentrations enhanced the silk filament size (Table, 3). Statistical analysis cleared high significant differences between the concentrations, while no significance was recorded between treatments.

The results obtained show that the effect of camphor on laveral growth that led to a significant increase due to being a disinfectant against bacterial, viral and fungi, which works to improve the performance of larvae which will be reflected on the production.

These results can be supported by Radha et al. (1980), Shoukry et al. (1998) and El-Sayed and Mosbah (1992) who stated that, volatile oils as nutritional additives improved the biological and technological characters of silkworm. Also, Sengupta et al. (1992), Zannon (1994), El-Sayed et al. (1998), Khalil et al. (2006), Fathy et al. (2008), Zannon et al. (2008) and Gad (2013) reported that improvement of mulberry leaves with some concentrations of honey bee leading to increase the silk filament characters. Wang and Johnson (2001), Panfili et al. (2003) and Hassan and Saad (2012) found that mulberry leaves supplemented with wheat oil offered to $4^{\text {th }}$ larval instar enhanced significantly all biotechnological characters. In the same trend, Saad et al (2014) found that the cocoon parameters and economical parameters were enhanced by $0.1 \%$ glycine treated larvae than control and other treated concentrations.

This study indicated that enriching mulberry leaves with the camphor honey and camphor oil can be used to increase the silk yield in commercial silkworm rearing.

\section{REFERENCES}

Angela, E. S. ND and W. L. MS. ND. Davis (2010): Immune-Modifying and antimicrobial effects of Eucalyptus oil and simple inhalation devices. Alternative Medicine Raview, Vol.15 (1):33:47.

Anonymous (1980): Effect of antibiotics on crop and incidence of loss due to disease Ann. Report 1979-80 CSR and TI, Mysore, 112-114.

El-Sayed, N. and H.A. Mosbah (1992): Effect of certain pharmaceutic vital compounds on the productivity of mulberry silk worm Bombyx mori L. (Lepidoptera: Bombycidae) Communications in Science and development Research Vol. 13 (2): 83-88.

El-Sayed, N.A.A.; H.A. Mosbah; W.H. Yehia and I.A. El-Karaksy (1998): Effect of two nutrient additive materials on the productivity of mulberry silkworm L. Advances in Agr. Res. Vol. 3 (2): 55-59. 
Fathy, H.M.; M.E. Ragab; Gad, Abeer A. and A. A. Ziton (2008): Effect of honey bee products on some biological parameters of the mulberry silk worm Bombyx mori L. J. Agric. Sci. Mansoura Univ., 33(5): 3659 3664.

Gad, Abir, A. (2013): Biological and Physiological Effects of Some Honey Bee Products and Its Mixtures as Nutritional Additives on Two Strains of The Mulberry Silkworm Bombyx mori. Alex. J. Agric. Res. Vol. 58 (1):47-52.

Harvey, W. F. and U. L. John (1898): King's American Dispensatory. 19 Edition, Third Revision Vol.2, The Ohio Valley, Company.

Hassan, Eman M. and M. I. S. Saad (2012): Biological and technologicaleffects of germ wheat oil as a nutritional additive on silkworm Bombyx mori growth. Egypt. J. Agric. Res., 90(2): 527-535.

Khalil, M.; T. Al-Abed and Omer, Eman (2006): Influence of Nutrient Supplements on silkworm Production of Bombyx Mori L. (Lepidoptera: Bombycidae) Tishreen University J. Studies and Scientific Research Biological Science Series Vol. 28 (1): 121:132

Konala, N.; P. Abburi; V.R. Bovilla and A. Mamillapalli (2013): The effect of bovine milk on the growth of Bombyx mori. J. Insect Science: Vol. 13 (98): 1:7.

Krishnaswami, S. (1978): New technology of silkworm rearing. Central Sericulture Researches and Training Institute. Mysore Bull, (2): 1-10.

Legay, JM. (1958): Recent advances in silkworm nutrition. Ann. Revi. of Entomol., Vol. 3:75-86.

Panfili, G.; L. Cinquanta; A. Fratianni and R.bCubadda (2003): Extraction of wheat germ oil by supercritical $\mathrm{Co}_{2}$ : oil and defatted cake characterization. J. American Oil Chemists Society. Vol. 80 (2): 157161.

Radha, N. V.; T. Natarajan; T. S. Muthukrishnan and G. Oblisami (1980): Effect of antibiotics of mulberry silkworm (ed. Muthukrishnanan, T. S. and Srirangaswamy, S. R.). Proc.Seric. Cymp. Coimbatore, 173-177.

Saad, I. A. I.; Taha Rehab H. and M.I.S. Saad (2014): Effect of Mulberry Leaves Enrichment with Amino Acid Glycine on the Biology of Silkworm, Bombyx mori L. Minufiya J. Agric. Res., 39 (2): 759-769.

Saad, M. I. S.; Hassan Eman M. and A. A. Zannoon (2012): Effect of some antibiotics on the biology and silk production of mulberry silkworm Bombyx mori L. Egypt. J. Agric. Res., 90(2): 537-545.

Sengupta, K; BD. Singh and JC. Mustafi (1992): Role of vitamins in silkworm nutrition. Indian J. of Seri. 11(1): 11-19.

Shoukry, I. F. I.; A. A. I. Zannoon; A. A. Khalaf and Hassan Eman M. (1998): Effect of some antibiotics and plant volatile oils on bacterial infection in mulberry silkworm Bombyx mori L. J. Union Arab Biol. Cairo Vol. 9(A), Zoology, 327-336.

Snedecor, G. W. and W. G. Cochran (1967): Statistical methods lowa State Univ. Press, Amer. lowa.

Tanaka, Y. (1964): Manual of Sericology. Central Silk Board, Bombay, (95)-B, Megdoot, Marine Drive, 216-220. 
Thilagavathi, G.; G. Selvisabhanayakam and P. P. Ganesh (2013): Studies on the impact of amoxicillin on growth rate and economic parameters Bombyx mori (L.) (Lepidoptera: Bombycidae) in relation to silk production. International J. of Current Research, Vol. 5(10): 3232-3237.

Wang, T. and L. Johnson (2001): Refining high-free fatty acid wheat germ oil J. of the American oil chemists' society. Vol. 78 (1): 71-76.

Zannoon, A. A. (1994): Effect of some nutritional additives on certain biological and productivity characters of mulberry silkworm, Bombyx mori L. J. of Prod. \& Dev. (Agri Research) (Institute of Efficient Productivity, Zagazig Univ., Egypt). 1: 19-24.

Zannoon, A. A. and Omra Shadia M. (1994): Efficiency of certain natural materials as mountages for mulberry silkworm, Bombyx mori L. Egypt. J. Appl. Sci., 9 (8): 691-696.

Zannoon, A. A.; Hassan Eman M.; Salah Somia E.; M. Abdel-Nabi and M. Z. Samy (2008): Biological and technological effects of mulberry varieties and nutritional additives on silkworm Bombyx mori development. Egyptian Journal of Biology, 2008, Vol. 10: 1-10

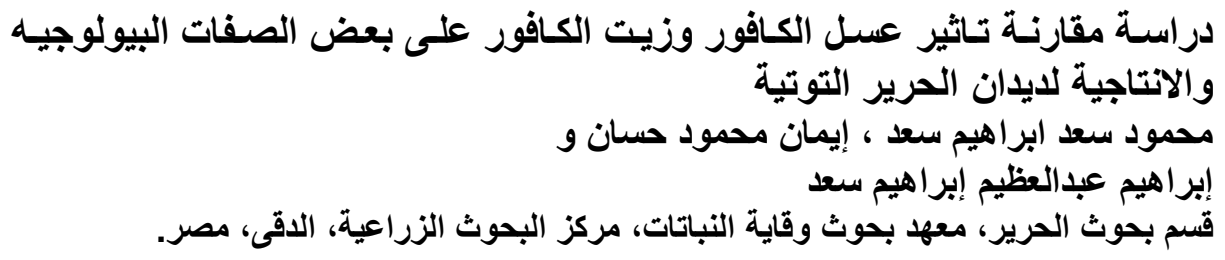

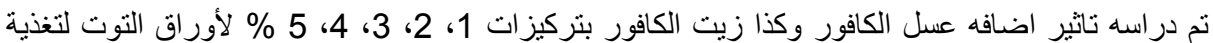

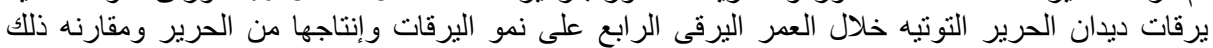

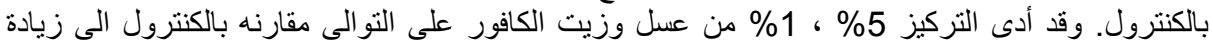

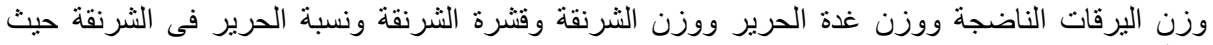

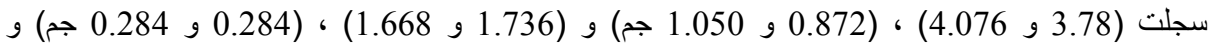

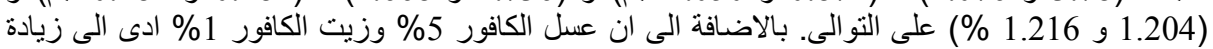

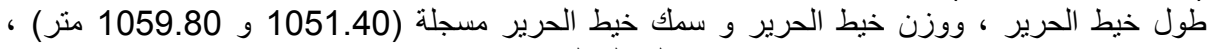
(0.28 , 0.27 جم) و (3.39 و 3.39 دنير) على التو الى. 
J. Plant Prot. and Path., Mansoura Univ., Vol.5 (5), May, 2014 